\title{
PEMANFAATAN URIN SAPI SEBAGAI BAHAN BAKU PUPUK ORGANIK CAIR (Studi Eksperimen Penambahan Aktifator Air Kelapa Dan Gula Merah Tahun 2017) Nurika Octa, Rachmaniyah, Imam Thohari
}

\begin{abstract}
Beef is one of waste waste from human activities. Cow's urine must be well managed in order to reduce environmental pollution. Management of bovine urine by means of turning it into a fertilizer in Add Activator coconut milk, brown sugar and EM4 can reduce environmental pollution and beneficial to the plant. The purpose of this research was to analyze the cow's urine as a liquid organic fertilizer raw materials

This type of research are True Experiment, with the design of the Posttest Only Control Group Design. Research methods to measure the levels of Nitrogen, phosphorus and Potassium in the treatment and control groups with a dose of a comparison of the coconut milk and brown sugar 240:16, 160:8 and 200:12. The location of the research carried out in the village of Tugu sub-district of Mantup Lamongan. Data is processed using tabulations further described with based on regulation of the Minister of agriculture no. 70/Permentan/SR 140/10/2011.

Test results measuring the levels of the most highest value NPK averaged ratanya in the treatment of 1 with doses of a comparison 240:16. For $\mathrm{pH}$ values all liquid fertilizer meet the standard is $5-6$. After applied on plants that grow quickly in plants that give fertilizer with a dose of 240:16.

The addition of the EM4, Activator coconut water and brown sugar can change the cow urine into fertilizer Liquid Nitrogen and potassium levels qualify yet for Phosphorus levels have not been qualified. Need to research more about the effective dose in the manufacture of liquid organic fertilizer that meets the terms of the regulation of the Minister of agriculture no. 70/Permentan/SR 140/10/2011 About Biological Fertilizers, organic fertilizers and Pembenah Soil.
\end{abstract}

Keywords : Cow urine, Activator coconut juice, brown sugar and EM4

\section{PENDAHULUAN}

Pengelolaan sampah dengan cara pengomposan atau mengubahnya menjadi pupuk merupakan salah satu alternatif yang dapat dilakukan. Dalam hal ini kegiatan ternak sapi setiap harinya dapat menghasilkan limbah yang dinamakan limbah ternak seperti kotoran sapi dan urin sapi.

Limbah ternak pada perkampungan dibiarkan saja atau dibuang begitu saja tanpa melalui proses pengolahan. Limbah ternak pasti bersifat kotor, mempunyai bau tidak sedap, menjijikkan dan lain lain. Limbah ternak ini sering menimbulkan masalah dari pada mendatangkan manfaat. Jika limbah ternak ini tidak dikelola dengan baik, akibatnya lingkungan sekitarnya akan tercemar, menurunkan mutu lingkungan atau kesehatan dan mengganggu kenikmatan hidup masyarakat.

Oleh karena itu perlu melalui proses daur ulang secara organik untuk menghasilkan produk pupuk cair dengan penambahan EM4 dan aktivator campuran air kelapa dan gula merah. 
METODE PENELITIAN

Penelitian ini merupakan penelitian eksperimen murni dengan menggunakan rancangan Posttest Only Control Group Design. Lokasi penelitian pembuatan bahan uji pupuk cair dilaksanakan di desa Tugu, Kecamatan Mantup Kabupaten Lamongan

Untuk obyek yang diambil dalam penelitian ini adalah sampah organik berupa urin sapi yang akan digunakan sebagai bahan baku pembuatan pupuk cair organik. Teknik pengumpulan data dilakukan dengan cara bahan uji urin sapi tanpa perlakuan (kontrol) dan urin sapi diberi perlakuan sebanyak 10 buah yang terbagi menjadi satu urin sapi tanpa perlakuan dan 3 variasi urin sapi perlakuan dengan dilakukan pengulangan sebanyak masing masing 3 kali. Analisis data menggunakan tabulasi yaitu data yang sudah terkumpul selanjutnya diolah dengan memasukkan dalam tabel dan dideskripsikan dengan berpedoman pada Peraturan Menteri Pertanian No.70/Permentan/SR.140/10/2011 Tentang Pupuk Organik, Pupuk Hayati dan Pembenah Tanah

\section{HASIL DAN PEMBAHASAN}

\section{Data Penelitian Kadar NPK Pada Pupuk Cair Organik}

\section{Tabel 1}

Data Pengukuran Kadar NPK Perbandingan 240:16

\begin{tabular}{|c|c|c|c|c|}
\hline No & $\begin{array}{c}\text { Kode } \\
\text { Sample }\end{array}$ & $\begin{array}{c}\text { Hasil } \\
\text { N \% }\end{array}$ & $\begin{array}{c}\text { Hasil } \\
\text { P \% }\end{array}$ & $\begin{array}{c}\text { Hasil } \\
\text { K \% }\end{array}$ \\
\hline 1 & R1 & 4,18 & 1,20 & 5,10 \\
\hline 2 & R2 & 4,22 & 1,16 & 5,13 \\
\hline 3 & R3 & 4,21 & 1,17 & 5,11 \\
\hline \multicolumn{2}{|c|}{ Rata - rata } & 4,20 & 1,17 & 5,11 \\
\hline
\end{tabular}

Berdasarkan tabel 1 bahwa kadar NPK yang di dapat setelah melalui uji laboratorium untuk perbandingan 240:16 hasilnya tidak jauh beda antara replikasi 1 , replikasi 2 dan replikasi 3. Untuk kadar $\mathrm{N}$ pada replikasi 1 yaitu 4,18\%, pada replikasi 2 kadar $\mathrm{N}$ yaitu $4,22 \%$ dan pada replikasi 3 yaitu $4,21 \%$ dengan rata rata $4,20 \%$. Untuk kadar $\mathrm{P}$ pada replikasi 1 yaitu $1,20 \%$, pada replikasi 2 yaitu $1,16 \%$ dan untuk replikasi 3 yaitu $1,17 \%$ dengan rata - rata $1,17 \%$. Untuk kadar $\mathrm{K}$ pada replikasi 1 yaitu $5,10 \%$, pada replikasi 2 yaitu $5,13 \%$ dan pada replikasi 3 yaitu $5,11 \%$ dengan rata - rata $5,11 \%$

\section{Tabel 2}

Data Pengukuran Kadar NPK Perbandingan 160:8

\begin{tabular}{|l|c|c|c|c|}
\hline No & $\begin{array}{c}\text { Kode } \\
\text { Sample }\end{array}$ & $\begin{array}{c}\text { Hasil } \\
\text { N \% }\end{array}$ & $\begin{array}{c}\text { Hasil } \\
\text { P \% }\end{array}$ & $\begin{array}{c}\text { Hasil } \\
\text { K \% }\end{array}$ \\
\hline 1 & R1 & 3,35 & 0,83 & 3,97 \\
\hline 2 & R2 & 3,39 & 0,79 & 4,02 \\
\hline 3 & R3 & 3,33 & 0,81 & 4,00 \\
\hline \multicolumn{2}{|c|}{ Rata - rata } & 3,35 & 0.81 & 3,99 \\
\hline
\end{tabular}

Dari tabel 2 bahwa kadar NPK yang di dapat setelah melalui uji laboratorium untuk perbandingan 160:8 hasilnya juga tidak jauh beda antara replikasi 1 , replikasi 2 dan replikasi 3. Untuk kadar $\mathrm{N}$ pada replikasi 1 yaitu 3,35\%, pada replikasi 2 yaitu $3,39 \%$ dan pada replikasi 3 yaitu $3,33 \%$ dengan rata - rata $3,35 \%$. Untuk kadar $\mathrm{P}$ pada replikasi 1 yaitu $0,83 \%$, pada replikasi 2 yaitu $0,79 \%$ dan untuk replikasi 3 yaitu $0,81 \%$ dengan rata - rata $0,81 \%$. Untuk kadar $\mathrm{K}$ pada replikasi 1 yaitu $3,97 \%$, pada replikasi 2 yaitu $4,02 \%$ dan pada replikasi 3 yaitu $4,00 \%$ dengan rata rata 3,99 . 
Tabel 3

Data Pengukuran Kadar NPK

Perbandingan 200:12

\begin{tabular}{|l|c|c|c|c|}
\hline No & $\begin{array}{c}\text { Kode } \\
\text { Sample }\end{array}$ & $\begin{array}{c}\text { Hasil } \\
\mathrm{N} \%\end{array}$ & $\begin{array}{c}\text { Hasil } \\
\mathrm{P} \%\end{array}$ & $\begin{array}{c}\text { Hasil } \\
\mathrm{K} \%\end{array}$ \\
\hline 1 & $\mathrm{R} 1$ & 3,79 & 1,01 & 4,16 \\
\hline 2 & $\mathrm{R} 2$ & 3,68 & 1,07 & 4,19 \\
\hline 3 & $\mathrm{R} 3$ & 3,71 & 1,07 & 4,13 \\
\hline \multicolumn{2}{|c|}{ Rata - rata } & 3,72 & 1,05 & 4,16 \\
\hline
\end{tabular}

Tabel IV.3menunjukkan bahwa kadar NPK yang di dapat setelah melalui uji laboratorium untuk perbandingan 200:12 hasilnya tidak jauh beda antara replikasi 1 , replikasi 2 dan replikasi 3 . Untuk kadar $\mathrm{N}$ pada replikasi 1 yaitu 3,79\%, pada replikasi 2 kadar $\mathrm{N}$ yaitu $3,68 \%$ dan pada replikasi 3 yaitu $3,71 \%$ dengan rata rata $3,72 \%$. Untuk kadar $\mathrm{P}$ pada replikasi 1 yaitu $1,01 \%$, pada replikasi 2 yaitu 1,07\% dan untuk replikasi 3 yaitu $1,07 \%$ dengan rata - rata $1,05 \%$. Untuk kadar $\mathrm{K}$ pada replikasi 1 yaitu $4,16 \%$, pada replikasi 2 yaitu 4,19\% dan pada replikasi 3 yaitu $4,13 \%$ dengan rata - rata 4,16 .

\begin{tabular}{|c|c|c|c|c|}
\hline \multicolumn{5}{|c|}{$\begin{array}{c}\text { Tabel IV.4 } \\
\text { Data Pengukuran Kadar NPK Urin } \\
\text { Sapi Tanpa Perlakuan }\end{array}$} \\
\hline No & $\begin{array}{c}\text { Kode } \\
\text { Sample }\end{array}$ & $\begin{array}{l}\text { Hasil } \\
\mathrm{N} \%\end{array}$ & $\begin{array}{l}\text { Hasil } \\
\text { P \% }\end{array}$ & $\begin{array}{l}\text { Hasil } \\
\mathrm{K} \%\end{array}$ \\
\hline 1 & Kontrol & 0,098 & 0,147 & 0,086 \\
\hline
\end{tabular}

Pada tabel 4 kadar NPK pada urin sapi tanpa perlakuan hasilnya jauh beda dengan urin sapi yang diberi perlakuan. Untuk kadar $\mathrm{N}$ hasilnya yaitu $0,098 \%$, untuk kadar $P$ hasilnya $0,147 \%$ dan untuk kadar $\mathrm{K}$ hasilnya $0,086 \%$.

\section{Pengukuran pH Pada Pupuk}

$\mathrm{pH}$ pupuk cair dari awal penelitian sampai pupuk jadi selama 7 hari bekisar antara 5-6. Berdasarkan hasil pengukuran $\mathrm{pH}$ pada pupuk cair dengan perbandingan 240:16, pebandingan 160:8 dan perbandingan 200:12 diperoleh $\mathrm{pH}$ yang sama, dengan kisaran $5-6$. Pengukuran $\mathrm{pH}$ dilakukan dengan menggunakan $\mathrm{pH}$ Indicatorpaper strips dengan kisaran 0 -14 .

$\mathrm{pH}$ tidak diatur sama sekali dan terjadi secara alami sesuai standar Peraturan Menteri Pertanian yaitu $\mathrm{pH}$ berkisar $4-9$. Pengamatan $\mathrm{pH}$ pupuk cair berfungsi sebagai indicator proses dekomposisi pupuk. Mikroba akan bekerja pada keadaan $\mathrm{pH}$ netral sampai sedikit asam, dengan kisaran pH $6-8$.

Pupuk organik cair yang dibuat harus memenuhi standar mutu agar kualitas yang dihasilkan sama dengan pupuk organik cair yang beredar dipasaran. Persyaratan teknis minimal pupuk cair yang beredar dipasaran dalam Peraturan Menteri Pertanian No. 70/ Permentan/ SR. 140/ 10/ 2011 tentang Pupuk Organik, Pupuk Hayati, Dan Pembenahan Tanah menentukan syarat teknis minimal yang harus dipenuhi oleh pupuk organik cair.

Persyaratan memuat berbagai parameter dengan standar mutu yang harus diikuti meliputi kadar C-organik, bahan ikutan, logam berat, tingkat keasaman dan pengujian terhadap kandungan kimia lainnya.

\section{Volume Pemberian Activator Yang}

\section{Optimal}

Berdasarkan hasil pengukuran pupuk organik cair di Laboratorium kadar NPK yang paling tertinggi yaitu pada volume perbandingan 240:16 dengan rata - rata kadar $\mathrm{N}$ (Nitrogen) sebesar $4,20 \%$, rata - rata kadar $\mathrm{K}$ 
(Kalium) sebesar 5,11\% yang sudah memenuhi syarat, tetapi untuk rata rata kadar $P$ (Fosfor) sebesar 1,17\% belum memenuhi standart Peraturan Mentri

PertanianNo.70/Permentan/SR.140/10 /2011 Tentang Pupuk Organik, Pupuk Hayati dan Pembenah Tanah.

Pupuk cair mengandung unsurunsur hara yang dibutuhkan untuk pertumbuhan, perkembangan, kesehatan tanaman. Unsur-unsur hara itu terdiri dari: Unsur Nitrogen $(\mathrm{N})$, untuk pertumbuhan tunas, batang dan daun. Unsur Fosfor $(P)$, untuk merangsang pertumbuhan akar buah, dan biji. Unsur Kalium (K), untuk meningkatkan ketahanan tanaman terhadap serangan hama dan penyakit. Pupuk cair ini memiliki keistimewaan yaitu lebih cepat diserap tanaman. kadar Fosfor pada pupuk cair organik ini belum memenuhi syarat di karenakan bahan tambahan pembuatan pupuk seperti gula merah hanya mempunyai kandungan fosfor sebanyak 37 kandungan unsure lainnya lebih besar seperti karbohidrat $76 \mathrm{~g}$, lemak $10 \mathrm{~g}$, protein $3 \mathrm{~g}$, kalsium $76 \mathrm{mg}$ dan bahan baku pupuk cair ini yang berupa urin sapi juga hanya mengandung unsur fosfor sebesar $0,01 \%$.

\section{Data Pertumbuhan Tanaman Cabai Rawit Selama 7 Minggu Setelah Pemberian Pupuk Cair}

Tabel 5

Pertumbuhan Tanaman Dengan Pupuk Perbandingan 240:16

\begin{tabular}{|c|r|r|r|r|r|r|}
\hline \multirow{2}{*}{$\begin{array}{c}\text { Minggu } \\
\text { Ke }\end{array}$} & \multicolumn{2}{|c|}{ Tanaman 1 } & \multicolumn{2}{c|}{ Tanaman 2 } & \multicolumn{2}{c|}{ Tanaman 3 } \\
\cline { 2 - 6 } & Batang & Daun & Batang & Daun & Batang & Daun \\
\hline 1 & $2,6 \mathrm{~cm}$ & $0,9 \mathrm{~cm}$ & $2,7 \mathrm{~cm}$ & $1 \mathrm{~cm}$ & $2,6 \mathrm{~cm}$ & $1 \mathrm{~cm}$ \\
\hline 2 & $3,9 \mathrm{~cm}$ & $1,1 \mathrm{~cm}$ & $4 \mathrm{~cm}$ & $1,2 \mathrm{~cm}$ & $3,7 \mathrm{~cm}$ & $1,2 \mathrm{~cm}$ \\
\hline 3 & $5,4 \mathrm{~cm}$ & $1,2 \mathrm{~cm}$ & $5,6 \mathrm{~cm}$ & $1,4 \mathrm{~cm}$ & $5,1 \mathrm{~cm}$ & $1,4 \mathrm{~cm}$ \\
\hline 4 & $8 \mathrm{~cm}$ & $1,9 \mathrm{~cm}$ & $8,2 \mathrm{~cm}$ & $1,9 \mathrm{~cm}$ & $8 \mathrm{~cm}$ & $1,7 \mathrm{~cm}$ \\
\hline 5 & $11,6 \mathrm{~cm}$ & $2,2 \mathrm{~cm}$ & $11,8 \mathrm{~cm}$ & $2,3 \mathrm{~cm}$ & $11,8 \mathrm{~cm}$ & $2,3 \mathrm{~cm}$ \\
\hline 6 & $13,1 \mathrm{~cm}$ & $2,8 \mathrm{~cm}$ & $13,4 \mathrm{~cm}$ & $2,9 \mathrm{~cm}$ & $13,2 \mathrm{~cm}$ & $2,8 \mathrm{~cm}$ \\
\hline 7 & $15,9 \mathrm{~cm}$ & $3,1 \mathrm{~cm}$ & $16 \mathrm{~cm}$ & $3,3 \mathrm{~cm}$ & $15,9 \mathrm{~cm}$ & $3,3 \mathrm{~cm}$ \\
\hline
\end{tabular}

Berdasarkan tabel 5 hasil pengamatan pertumbuhan tanaman yang sudah diberi pupuk dengan perbandingan 240:16 selama 7 minggu yaitu pada minggu ke1 tanaman ke 1 panjang batang 2,6 cm dan lebar daun $0,9 \mathrm{~cm}$ pada tanaman ke 2 dan ke 3 lebar daun sama yaitu 1 
cm tetapi panjang batang tanaman ke 2 yaitu $2,7 \mathrm{~cm}$ dan ke 3 yaitu $2,6 \mathrm{~cm}$.

Minggu ke 3 panjng batang 5,4 $\mathrm{cm}$ dengan lebar daun $1,2 \mathrm{~cm}$ dan untuk tanaman ke 2 dan ke 3 lebar daun sama yaitu $1,4 \mathrm{~cm}$ dan panjang batang masing - masing 5,6 cm untuk tanaman k3 2 dan 5,1 cm untuk tanaman ke 3.

Minggu ke 7 pada tanaman 1 dan 2 panjang batang yaitu $15,9 \mathrm{~cm}$ dan lebar daun 3,1 untuk tanaman 1, pada tanaman 2 panjang batang 16 $\mathrm{cm}$ dan lebar daun $3,3 \mathrm{~cm}$ untuk tanaman ke 2 dan ke 3
Unsur hara $\mathrm{N}$ yang terkandung di dalam urin sapi juga sangat mempengaruhi dalam perkembangan daun, sehingga menghasilkan jumlah daun yang berbeda. Sesuai pernyataan Lingga dan Marsono (2007) yang mengatakan bahwa peranan utama $\mathrm{N}$ bagi tanaman adalah untuk merangsang pertumbuhan secara keseluruhan, khususnya batang, cabang, dan daun. Selain itu $\mathrm{N}$ berperan penting dalam pembentukkan hijauan daun yang sangat berguna dalam proses fotosintesis.

Tabel 6

Pertumbuhan Tanaman Dengan Pupuk Perbandingan 160:8

\begin{tabular}{|c|r|r|r|r|r|r|}
\hline \multirow{2}{*}{$\begin{array}{c}\text { Minggu } \\
\text { Ke }\end{array}$} & \multicolumn{2}{|c|}{ Tanaman 1 } & \multicolumn{2}{c|}{ Tanaman 2 } & \multicolumn{2}{c|}{ Tanaman 3 } \\
\cline { 2 - 7 } & Batang & Daun & Batang & Daun & Batang & Daun \\
\hline 1 & $2 \mathrm{~cm}$ & $0,8 \mathrm{~cm}$ & $2 \mathrm{~cm}$ & $0,8 \mathrm{~cm}$ & $2 \mathrm{~cm}$ & $0,8 \mathrm{~cm}$ \\
\hline 2 & $2,9 \mathrm{~cm}$ & $0,9 \mathrm{~cm}$ & $3 \mathrm{~cm}$ & $1 \mathrm{~cm}$ & $2,9 \mathrm{~cm}$ & $0,9 \mathrm{~cm}$ \\
\hline 3 & $3,8 \mathrm{~cm}$ & $1,1 \mathrm{~cm}$ & $4,1 \mathrm{~cm}$ & $1,2 \mathrm{~cm}$ & $3,8 \mathrm{~cm}$ & $1 \mathrm{~cm}$ \\
\hline 4 & $7 \mathrm{~cm}$ & $1,4 \mathrm{~cm}$ & $6,8 \mathrm{~cm}$ & $1,5 \mathrm{~cm}$ & $7 \mathrm{~cm}$ & $1,4 \mathrm{~cm}$ \\
\hline 5 & $9,9 \mathrm{~cm}$ & $1,9 \mathrm{~cm}$ & $10,5 \mathrm{~cm}$ & $1,9 \mathrm{~cm}$ & $10,3 \mathrm{~cm}$ & $1,8 \mathrm{~cm}$ \\
\hline 6 & $12,3 \mathrm{~cm}$ & $2 \mathrm{~cm}$ & $12,3 \mathrm{~cm}$ & $2,1 \mathrm{~cm}$ & $12 \mathrm{~cm}$ & $1,9 \mathrm{~cm}$ \\
\hline 7 & $13,8 \mathrm{~cm}$ & $2,3 \mathrm{~cm}$ & $14 \mathrm{~cm}$ & $2,5 \mathrm{~cm}$ & $13,8 \mathrm{~cm}$ & $2,3 \mathrm{~cm}$ \\
\hline
\end{tabular}

Dari tabel 6 hasil pengamatan pertumbuhan tanaman cabai rawit yang sudah di beri pupuk dengan perbandingan 160:8 selama 7 minggu yaitu pada minggu ke 1 semua tanaman panjang batang $2 \mathrm{~cm}$ dan lebar daun $0,8 \mathrm{~cm}$. Minggu ke 3 panjang batang tanaman ke 1 dan ke 3 yaitu $3,8 \mathrm{~cm}$ dan lebar daun masing - masing yaitu $1,1 \mathrm{~cm}$ dan $1 \mathrm{~cm}$, tanaman ke 2 panjang batang $4,1 \mathrm{~cm}$ lebar daun $1,2 \mathrm{~cm}$.

Minggu ke 7 tanaman ke 1 dan 3 mempunyai panjang batang 13,8 cm dan lebar daun $2,3 \mathrm{~cm}$, untuk tanaman ke 2 panjang batang $14 \mathrm{~cm}$ dan lebar daun $2,5 \mathrm{~cm}$.

Kandungan unsur hara yang terdapat pada urine sapi sangat dibutuhkan oleh tanaman tidak terlepas dari proses fermentasi yang dilakukan sebelum diberikan pada tanaman. Naswir dkk (2009), mengatakan bahwa sifat fisik dan kimia urine sapi yang difermentasi memperlihatkan penambahan konsentrasinya jika dibandingkan dengan urine sapi nonfermentasi. Urin sapi berbentuk cair akan memiliki banyak kelebihan, diantaranya 
sebagai sumber nutrisi bagi tanaman yang mudah diserap oleh tanaman juga dapat membantu menyerap air. Penyerapan air oleh tanaman akan membantu penyerapan hara sehingga mempengaruhi perkembangan vegetatif tanaman.

Tabel 7

Pertumbuhan Tanaman Dengan Pupuk Perbandingan 200:12

\begin{tabular}{|c|r|r|r|r|r|r|}
\hline \multirow{2}{*}{$\begin{array}{c}\text { Minggu } \\
\text { Ke }\end{array}$} & \multicolumn{2}{|c|}{ Tanaman 1 } & \multicolumn{2}{c|}{ Tanaman 2 } & \multicolumn{2}{c|}{ Tanaman 3 } \\
\cline { 2 - 7 } & Batang & Daun & Batang & Daun & Batang & Daun \\
\hline 1 & $2,4 \mathrm{~cm}$ & $0,9 \mathrm{~cm}$ & $2,3 \mathrm{~cm}$ & $0,8 \mathrm{~cm}$ & $2,4 \mathrm{~cm}$ & $0,9 \mathrm{~cm}$ \\
\hline 2 & $3,2 \mathrm{~cm}$ & $1 \mathrm{~cm}$ & $3,1 \mathrm{~cm}$ & $1 \mathrm{~cm}$ & $3,1 \mathrm{~cm}$ & $1 \mathrm{~cm}$ \\
\hline 3 & $5,1 \mathrm{~cm}$ & $1,2 \mathrm{~cm}$ & $4,8 \mathrm{~cm}$ & $1,1 \mathrm{~cm}$ & $5,1 \mathrm{~cm}$ & $1,2 \mathrm{~cm}$ \\
\hline 4 & $7,2 \mathrm{~cm}$ & $1,7 \mathrm{~cm}$ & $6,7 \mathrm{~cm}$ & $1,6 \mathrm{~cm}$ & $6,8 \mathrm{~cm}$ & $1,6 \mathrm{~cm}$ \\
\hline 5 & $10,5 \mathrm{~cm}$ & $2,1 \mathrm{~cm}$ & $9,8 \mathrm{~cm}$ & $2 \mathrm{~cm}$ & $10 \mathrm{~cm}$ & $2 \mathrm{~cm}$ \\
\hline 6 & $12,4 \mathrm{~cm}$ & $2,5 \mathrm{~cm}$ & $11,7 \mathrm{~cm}$ & $2,3 \mathrm{~cm}$ & $12,1 \mathrm{~cm}$ & $2,3 \mathrm{~cm}$ \\
\hline 7 & $15,4 \mathrm{~cm}$ & $2,9 \mathrm{~cm}$ & $14,1 \mathrm{~cm}$ & $2,8 \mathrm{~cm}$ & $15,2 \mathrm{~cm}$ & $2,8 \mathrm{~cm}$ \\
\hline
\end{tabular}

Tabel 7 menunjukkan hasil pengamatan pertumbuhan tanaman cabai rawit yang sudah di beri pupuk dengan perbandingan 200:12 selama 7 minggu yaitu pada minggu ke 1 tanaman ke 1 dan 3 panjang batang $2,4 \mathrm{~cm}$ dan lebar daun $0,9 \mathrm{~cm}$, untuk tanaman ke 2 panjang batang 2,3 cm dan lebar daun $0,8 \mathrm{~cm}$.

Minggu ke 3 untuk tanaman ke 1 da 3 panjang batang $5,1 \mathrm{~cm}$ lebar daun $1,2 \mathrm{~cm}$, tanaman ke 2 panjang batang $4,8 \mathrm{~cm}$ dal lebar daun $1,1 \mathrm{~cm}$. Minggu ke 7 lebar daun 2,8 cm pada tanaman ke 2 dan 3, panjang batang masing - masing $14,1 \mathrm{~cm}$ dan 15,2 $\mathrm{cm}$, tanaman ke 1 panjang batang $15,4 \mathrm{~cm}$ lebar daun $2,9 \mathrm{~cm}$.

Tanaman yang pertumbuhan nya lebih cepat kemungkinan unsur yang diperlukan tanaman sudah memenuhi syarat. Unsur N (Nitrogen) di gunakan tanaman sebagai pembentuk protein dan klorofil. Pembentukan klorofil akan menghasilkan karbohidrat yang digunakan untuk tanaman sebagai makanan. Protein juga dapat mempengaruhi pertumbuhan sel vegetatif karena protein berperan penting sebagai katalisator dan pengatur metabolisme. 
Tabel IV.8

Pertumbuhan Tanaman Dengan Pupuk Kontrol

\begin{tabular}{|c|c|c|}
\hline \multirow{2}{*}{ Minggu Ke } & \multicolumn{2}{|c|}{ Tanaman 1 } \\
\cline { 2 - 3 } & Batang & Daun \\
\hline 1 & $2 \mathrm{~cm}$ & $0,7 \mathrm{~cm}$ \\
\hline 2 & $3,2 \mathrm{~cm}$ & $0,9 \mathrm{~cm}$ \\
\hline 3 & $4,2 \mathrm{~cm}$ & $1,2 \mathrm{~cm}$ \\
\hline 4 & $5,2 \mathrm{~cm}$ & $1,4 \mathrm{~cm}$ \\
\hline 5 & $6 \mathrm{~cm}$ & $1,5 \mathrm{~cm}$ \\
\hline 6 & $8 \mathrm{~cm}$ & $1,7 \mathrm{~cm}$ \\
\hline 7 & $9,8 \mathrm{~cm}$ & $1,9 \mathrm{~cm}$ \\
\hline
\end{tabular}

Pada tabel IV.8 hasil pengamatan pertumbuhan tanaman cabai rawit yang sudah di beri pupuk kontrol selama 7 minggu yaitu pertumbuhannya sangat lambat yang ditunjukkan pada minggu ke 1 panjang batang $2 \mathrm{~cm}$ lebar daun $0,7 \mathrm{~cm}$, minggu ke 2 panjang batang $3,2 \mathrm{~cm}$ lebar daun $0,9 \mathrm{~cm}$, minggu ke 3

\section{KESIMPULAN DAN SARAN}

\section{Kesimpulan}

1. Hasil Pengukuran Kadar NPK

- Kadar NPK pada pupuk cair dengan dosis perbandingan 240:16 dengan rata - rata kadar $\mathrm{N}=4,20 \%$, kadar $\mathrm{P}=1,17 \%$, kadar $\mathrm{K}=5,11 \%$ namun kurang memenuhi syarat Peraturan Menteri Pertanian No.70/Permentan/SR.140/10/201 1 Tentang Pupuk Organik, Pupuk Hayati dan Pembenah Tanah dikarenakan kadar $\mathrm{P}$ tidak sesuai peraturan yaitu $<3 \%$

- Kadar NPK pada pupuk cair dengan dosis perbandingan 160 : 8 dengan rata - rata kadar $\mathrm{N}=$ $3,35 \%$, kadar $\mathrm{P}=0,81 \%$, kadar panjang batang 4,2 cm lebar daun 1,2 $\mathrm{cm}$, minggu ke 4 panjang batang 5,2 $\mathrm{cm}$ lebar daun $1,4 \mathrm{~cm}$, minggu ke 5 panjang batang $6 \mathrm{~cm}$ lebar daun 1,5 $\mathrm{cm}$, minggu ke 6 panjang batang $8 \mathrm{~cm}$ lebar daun $1,7 \mathrm{~cm}$, minggu ke 7 panjang batang $9,8 \mathrm{~cm}$ lebar daun 1,9 $\mathrm{cm}$.

$\mathrm{K}=3,99 \%$ namun kurang memenuhi syarat Peraturan Menteri Pertanian No.70/Permentan/SR.140/10/201 1 Tentang Pupuk Organik, Pupuk Hayati dan Pembenah Tanah dikarenakan kadar $\mathrm{P}$ tidak sesuai peraturan yaitu $<3 \%$

- Kadar NPK pada pupuk cair dengan dosis perbandingan 200:12 dengan rata - rata kadar $\mathrm{N}=3,72 \%$, kadar $\mathrm{P}=1,05 \%$, kadar $\mathrm{K}=4,16 \%$ namun kurang memenuhi syarat Peraturan Menteri Pertanian No.70/Permentan/SR.140/10/201 1 Tentang Pupuk Organik, Pupuk Hayati dan Pembenah Tanah dikarenakan kadar $\mathrm{P}$ tidak sesuai peraturan yaitu $<3 \%$ 
2. Hasil pengukuran pH pupuk cair dari awal penelitian sampai pupuk jadi selama 7 hari berkisar antara 5 - 6. Hal tersebut sudah memenuhi syarat Peraturan Menteri Pertanian No.70/Permentan/SR.140/10/2011 Tentang Pupuk Organik, Pupuk Hayati dan Pembenah Tanah yaitu $4-9$.

3. Dari hasil pengamatan yang sudah dilakukan volume pemberian aktivator yang paling optimal yaitu pada perbandingan 240:16 dengan rata - rata $\mathrm{N}=4,20 \% \mathrm{P}=1,17 \% \mathrm{~K}=$ $5,11 \%$

4. Dari hasil pengamatan tanaman yang sudah diberi pupuk cair dengan dosis perbandingan yang

\section{DAFTAR PUSTAKA}

Alviani, K.D, 2016. “ Pengaruh

Konsentrasi Gula Kelapa dan Starter Acetobacter xylinum Terhadap Kualitas Fisik Dan Kimiawi Nata De Leri ". Skripsi. Jurusan Biologi, Fakultas Sains dan Teknologi, Universitas Islam Negeri Maulana Malik Ibrahim Malang.

http://etheses.uin-

malang.ac.id/2883/1/11620040. $\underline{\mathrm{pdf}}$

Benito, A.K, dkk, 2013. "Pemanfaatan Feses Sapi Perah Menjadi Pupuk Cair dengan Penambahan Saccharomyces cerevisiae". Jurnal IImu Ternak, Vol 13 No.2.: 18

Darwin Philips.2013.Menikmati Gula Tanpa Rasa Takut. Perpustakaan Nasional: Sinar IImu.

Djuarnani, N., Kristia, B.S., Setiawan, berbeda - beda, tanaman yang pertumbuhannya lebih cepat yaitu pada tanaman yang diberi pupuk dengan dosis perbandingan 240:16

\section{Saran}

1. Sebaiknya untuk peneliti selanjuntnya bisa melakukan penambahan dosis untuk air gula merahnya agar berpengaruh nyata terhadap kualitas pupuk cair organik

2. Penambahan bahan lain dapat dilakukan seperti abu arang batu bara untuk meningkatkan kadar fosfor yang sangat kurang pada pupuk cair organik yang berbahan baku urin sapi.
2005. Cara Tepat Membuat Kompos. Agromedia Pustaka, Jakarta

Hadisuwito, Sukamto, 2008. Membuat Pupuk Kompos Cair. Jakarta : PT Agro Media Pustaka.

Hadisuwito, Sukamto, 2012. Membuat Pupuk Organik Cair. Jakarta : PT Agro Media Pustaka ; 5-18

Huda, M.K., 2013. "Pembuatan Pupuk Organik Cair Dari Urin Sapi Dengan Aditif Tetes Tebu (Molasses) Metode Fermentasi". Skripsi. Jurusan Kimia, Fakultas Matematika dan IImu Pengetahuan Alam, Universitas NegeriSemarang http://lib.unnes.ac.id/17837/1/43 50408012.pdf27 September 2016

Lovakusuma, L.S, 2015."Pemanfaatan Sludge Limbah Food And Beverage Sebagai Aktivator Proses Pengomposan Sampah 
Pasar Puspa Agro Sidoarjo". Karya Tulis IImiah. Jurusan Kesehatan Lingkungan, Poltekkes Kemenkes Surabaya

Lingga, pinus dan Marsono, 2013.

Petunjuk Penggunaan Pupuk. Jakarta : Penebar Swadaya : 25 $-26$

Notoatmodjo, S., 2012. Metodelogi Penelitian Kesehatan. Jakarta : Rineka Cipta :59 - 60

Parnata, A.S., 2004. Pupuk Organik Cair Aplikasi dan Manfaatnya. Jakarta : Agro Media Pustaka: 61

Peraturan Menteri Pertanian No.70/Permentan/SR.140/10/20 11 Tentang Pupuk Organik, Pupuk Hayati dan Pembenah Tanah

Purwendro, Setyo dan Nurhidayat, 2006. Mengolah Sampah untuk Pupuk \& Pestisida Organik. Jakarta : Penebar Swadaya

Riansyah, Erwin dan Wesen .P., 2012. Pemanfaatan Lindi Sampah Sebagai Pupuk Cair. Jurnal Ilmiah Teknik Lingkungan,Vol 4 No.1

https://core.ac.uk/download/pdf/ 12219325.pdf25 September $\underline{2016}$

Soeryoko, Hery, 2011. Kiat Pintar Memproduksi Kompos dengan Pengurai Buatan Sendiri: 13 16

Sriyanto, 2009. "Pembuatan Pupuk Cair Dari Sampah Organik Dengan Menggunakan Em4
(Effective Microorganism)Dan Air KelapaSebagai Starter "Skripsi.Departemen Teknologi Pertanian, Fakultas Pertanian, Universitas Sumatra Utara

Susetyo, N.A., 2013. Pemanfaatan Urin Sapi Sebagai POC (Pupuk Organik Cair) Dengan Penambahan Akar Bambu Melalui Proses Fermentasi Dengan Waktu Yang Berbeda. Skripsi. Jurusan Keguruan dan IlmuPendidikan, Program Studi Pendidikan Biologi, Universitas Muhammadiyah Surakarta http://eprints.ums.ac.id/26749/2 4/NASKAH PUBLIKASI.pdf5 Januari 2017

Tim Penulis PS, 2008. Penanganan \& Pengolahan Sampah. Jakarta : Penebar Swadaya : 5-6

Undang - Undang Nomor 18 Tahun 2008 Tentang Pengelolaan Sampah.

Utomo, A, S. 2007. Pembuatan

Kompos Dengan Limbah Organik. Jakarta: CV Sinar Cemerlang Abadi

Yulianto, Purnawan dan Saparinto .C., 2014. Beternak Sapi Limousin. Jakarta : Penebar Swadaya : 69

Yuliarti, Nurheti, 2009. 1001 Cara untuk Menghasilkan Pupuk Organik. Yogyakarta : Lily Publisher : 6 - 8

Yuliatin, I.S, 2011. Mukjizt Air Kelapa. Surabaya : PT Java Pustaka Grup : 9, 64-65 